\title{
The analysis of visual variables for use in the cartographic design of point symbols for mobile Augmented Reality applications
}

\author{
Lukasz Halik \\ Department of Cartography and Geomatics, Adam Mickiewicz University Poznan, \\ Collegium Geographicum, 27 Dziegielowa St., 61-680 Poznan, Poland \\ e-mail: lhalik@amu.edu.p
}

Received: 24 April2012/Accepted: 20 June 2012

\begin{abstract}
The objective of the present deliberations was to systematise our knowledge of static visual variables used to create cartographic symbols, and also to analyse the possibility of their utilisation in the Augmented Reality (AR) applications on smartphone-type mobile devices. This was accomplished by combining the visual variables listed over the years by different researchers. Research approach was to determine the level of usefulness of particular characteristics of visual variables such as selective, associative, quantitative and order. An attempt was made to provide an overview of static visual variables and to describe the AR system which is a new paradigm of the user interface.

Changing the approach to the presentation of point objects is caused by applying different perspective in the observation of objects (egocentric view) than it is done on traditional analogue maps (geocentric view). Presented topics will refer to the fast-developing field of cartography, namely mobile cartography. Particular emphasis will be put on smartphone-type mobile devices and their applicability in the process of designing cartographic symbols.
\end{abstract}

Keywords: visual variables, cartographic symbols, Augmented Reality, smartphone

\section{Introduction}

Point symbols are an indispensable element of maps, in particular tourist maps, and visual variables play a key role in their creation. According to Tyner (2010) visual variables of symbol are its graphic characteristics which permit the differentiation of symbols by the characteristics and values they represent. A simple geometric symbol may be constructed using a single visual variable; however, for this purpose a few variables are used; their selection and that of their parameters plays a key role in the process of conveying spatial information.

More and more frequently, contemporary map applications are created in an egocentric architecture (Meng, 2005), where the user occupies an important role in the elaboration of the cartographic message. This state of affairs is brought about by technological changes occurring in the modern IT society. Due to the progress in data acquisition and data processing technologies, real-world data has been recently stored and collected in large amounts (Špatenková et al., 2007). The main role therein 
is played by the need for immediate access to information, which is possible thanks to the usage of mobile devices, smartphones in particular. Gotlib (2011) defines the smartphone as a mobile telephone with developed functionalities typical of PDA-type devices (Personal Digital Assistant). Growing rise of mobile devices, increasing the need to access information anywhere and at any time, and to better manage data. These goals have driven the design of AR systems (Barfield and Caudell, 2001). Due to their construction, devices of this type support the implementation of the Augmented Reality system, which is a new paradigm of the user interface, which aims to amplify a user's sensory perception directly by supplementing computer generated, mostly visual information (Schmalstieg and Reitmayr, 2006). AR allows the user to see the real world. Therefore, AR supplements reality, rather than completely replacing it (Azuma, 1997). Using AR makes it easier to see additional information superimposed in the field of observation (Danado et al., 2005). Höllerer and Feiner (2004) define an AR system as one that combines real and computer-generated information in a real environment, interactively and in real time, and aligns virtual objects with physical ones.

The visualisation of spatial information in AR is connected with a change in the approach to the method of presenting point objects. First and foremost, this concerns a different method of projecting objects on the map base than the one applied for traditional analogue maps. An additional factor determining symbol design concerns their ability to handle associations, their attractiveness and originality, as well as the observance of basic cartographic design principles applicable to point symbols (Medyńska-Gulij, 2008).

\section{Methodology}

The objective of the present deliberations was to systematise our knowledge of static visual variables used to create cartographic signatures, and also to analyse the possibility of their utilisation in the AR system on smartphone-type mobile devices. This was effected by comparing the entirety of variables detailed over the years by various researchers. The point of departure for the whole comparison were static visual variables determined by Bertin (1967/83). The new approach consisted in establishing the degree of usefulness of individual characteristics of visual variables, among others selective, associative, quantitative and order. The article comprises the following elements: a description of the architecture of smartphone-type mobile devices, a description of the dynamic, egocentric AR interface with reference to analogue maps, and - finally a breakdown of visual variables together with an assessment of their usefulness for presentation purposes in the AR system on a smartphone.

\subsection{Theoretical background of visual variables}

Bertin (1967/83) was the first to distinguish and classify visual variables: size, shape, value, colour, orientation and texture (Fig.1.). In the light of the contemporary develop- 


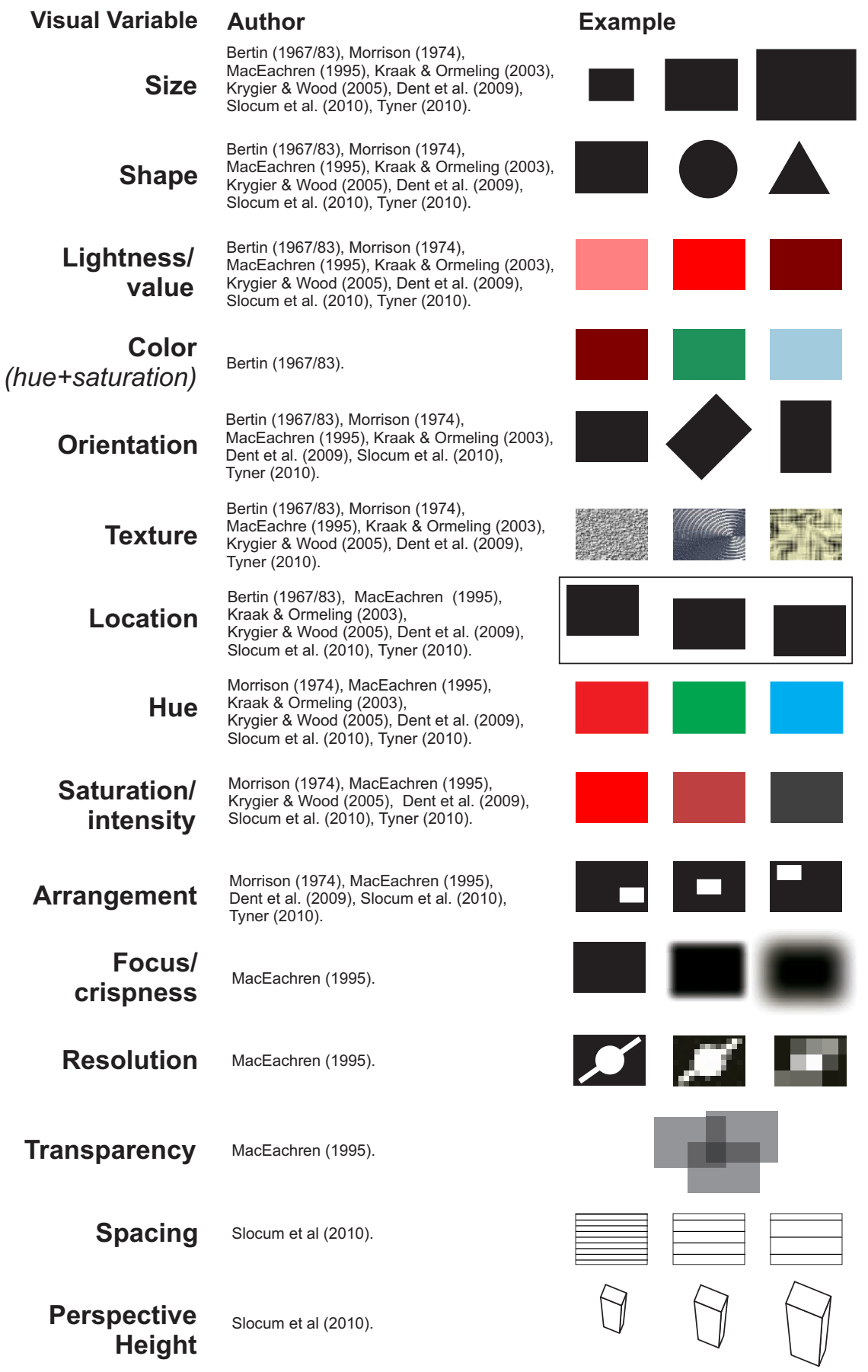

Fig. 1. Breakdown of static visual variables 
ment of cartography, these variables should be considered as static. They take part in the creation of cartographic signatures that comprise maps. Figure 1 provides a chronological presentation of the visual variables distinguished by the cartographers over the last fifty years. This table will help to systematize the knowledge about the variables and bring out a certain group variables, most widely accepted by the cartographic society. Static visual variables most frequently mentioned in literature are as follows: size, shape, lightness / value, orientation, texture, location, hue, saturation / intensity and arrangement. Over the years, the body of knowledge concerning the present topic has undergone a considerable theoretical consolidation. We should mention the work of Morrison (1974), in which he was the first to propose the addition of new variables: arrangement and saturation (third dimension of colour). According to MacEachren (1995), the basic visual variables distinguished by Bertin are insufficient to visualise the phenomenon of uncertainty, and for this reason he proposed expanding the list by additional variables: crispness, resolution and transparency. When referring to the previous classification, Kraak and Ormeling (2003) and Krygier and Wood (2005) confirm its usefulness in the process of creating cartographic symbols without the introduction of additional changes. The list was expanded by spacing and perspective height by Slocum et al. (2005). The most important publications include works by Dent et al. (1999) and Tyner (2010); although these authors did not introduce any changes to previously proposed classifications.

\subsection{Architecture of AR systems and features of smartphone-type mobile devices}

According to MacWilliams et al. (2004) all Augmented Reality systems are interactive systems and the core functionality of AR is the same for all systems: tracking the user's position, mixing real and virtual objects, and processing and reacting to context changes and user interactions.

Most AR systems on smartphone-type mobile devices share a common basic architectural structure. They are built of six core subsystems (Fig. 2) e.g.: application, interaction, presentation, tracking, context and world model subsystem. Each of them provides a particular functionality for the whole system. Four subsystems are coded into the smartphone (i.e. the AR browser). The Application subsystem is responsible for the main control flow logic of the application and coordinating communication between other subsystems. The Interaction subsystem collects and computes any input that the user makes deliberately. The Tracking system is responsible for responding to changes in the user's location and orientation in the Real Environment and providing it to other subsystems e.g. the presentation subsystem which displays output (3D models, 2D graphics, text or audio) for the user. Context subsystem is separate subsystem located on a Web Platform. It collects different types of context data providing it to other subsystems. This includes for example user preferences and the current user task. World Model subsystem is also implemented outside the smartphone's browser. It stores and provides access to a digital representation of the world including Point Of Interest (POI) which are linked to real-world objects or user positions. 


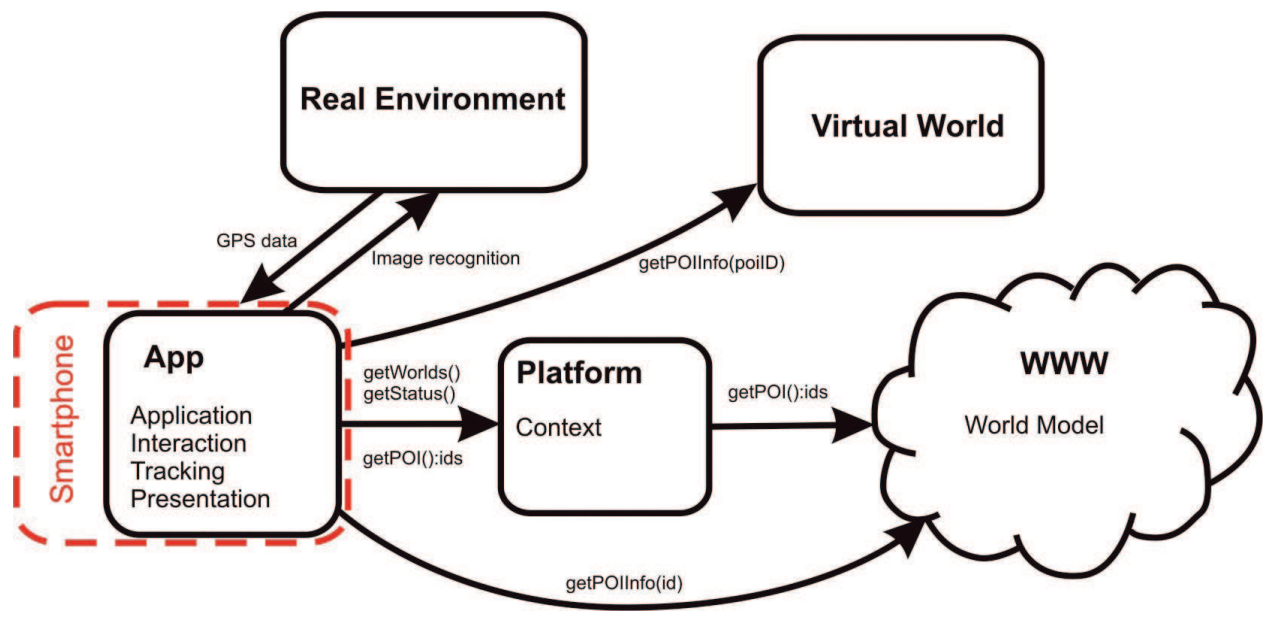

Fig. 2. General architecture of AR systems of smartphone-type mobile devices (adapted from Butchart, 2011)

Smartphone-type mobile devices are equipped with a number of components enabling the implementation of the AR system, including, among others, a high-resolution display, a GPS module, an electronic compass, a digital camera, an accelerometer, a gyroscope, and GSM/Wi-Fi communication. In connection with the spatial database, the above elements make it possible to display virtual graphics on the screen of the mobile device. The graphics constitute point symbols, for which the camera image is the background and a spatial reference.

The device determines its spatial location in the WGS-84 system by means of a GPS system. The precision with which the position is determined in the open is at maximum $\pm 2 \mathrm{~m}$ (HTC Desire). The electronic compass takes a bearing on a given object, i.e. one towards which the camera lens is directed; precision is within the range of $4^{\circ}$. The role of the gyroscope is to determine the angle of deviation from the horizontal and the vertical; in standard smartphones its precision is $0.2^{\circ}$. The width of the image registered by the camera lens totals approximately $60^{\circ}$.

\subsection{Difference between symbology on AR map applications and on static touristic map}

On analogue maps, the approach to the method of conveying cartographic contents is geocentric (Meng, 2005). Cartographic contents in the form of symbols is placed on the flat surface of the map in keeping with an orthogonal projection, and this eliminates any perspective, although symbols on the map do have features of a view created in a parallel perspective. Cartography makes use of forms of spatial presentation such as profiles, the cavalry perspective, and the military perspective, which utilise geometrical principles typical of the parallel perspective (Medyńska-Gulij, 2011). In 
map applications for mobile devices used in motor-car navigation systems, symbols are placed mainly in a parallel perspective without any change in size in $2 \mathrm{D}$ and $3 \mathrm{D}$ views (Fig. 3). In the case of the $2 \mathrm{D}$ view, projecting rays pierce the projection surface perpendicularly, while in the $3 \mathrm{D}$ view the projection is performed onto the oblique image surface with perpendicular projecting rays.
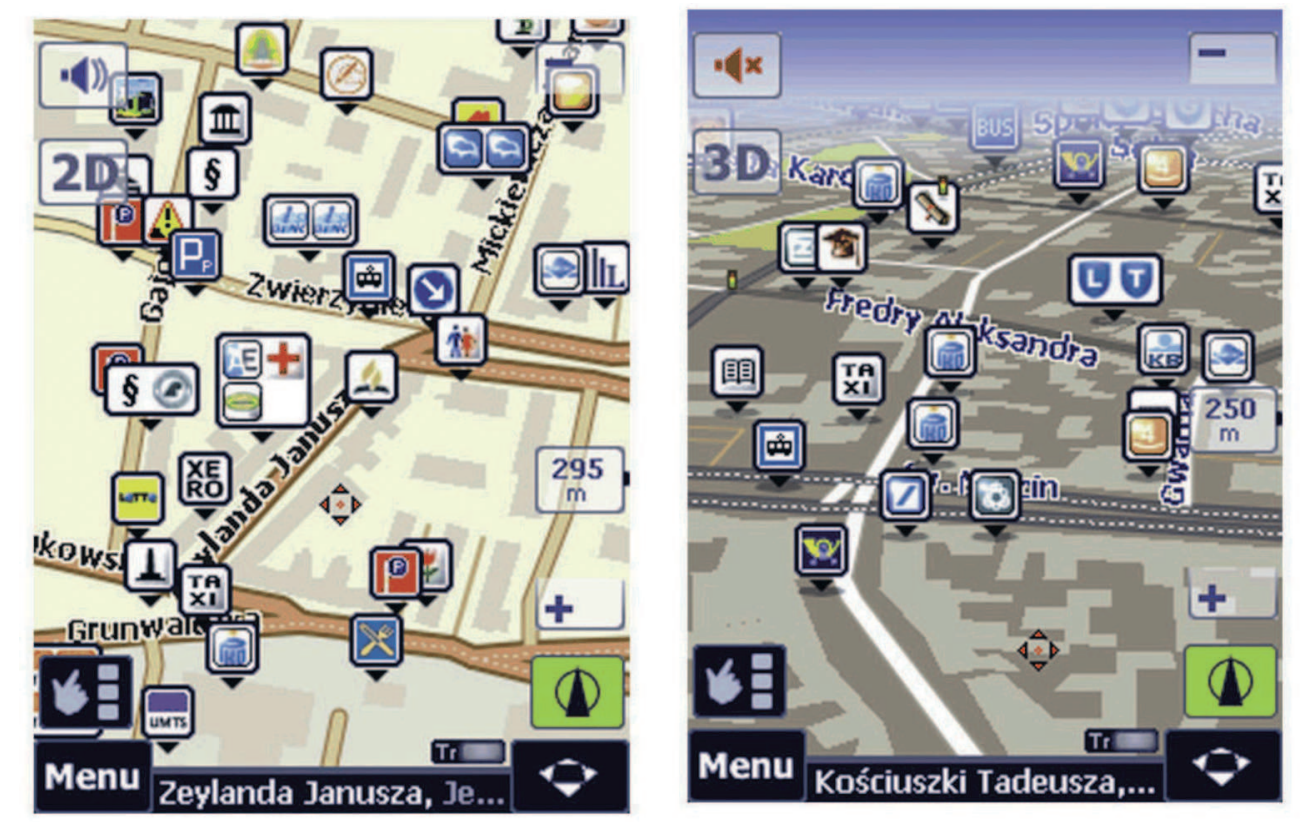

Fig. 3. Placement of symbols on map application for mobile devices for navigation in a 2D and 3D view (AutoMapa applications; manufacturer: Akurat Ltd.,Geosystems Poland Ltd.)

A completely different approach should be taken to the issue of elaborating point symbols in the AR system, where we are dealing with a central perspective in the form of virtual graphics. The arrangement of symbols on the smartphone's screen depends on the distance between the observer and the object, and placement with respect to the centre of the smartphone screen. The projection surface is perpendicular to the horizontal reference surface, just as when creating a panorama. Figure 4 presents the difference of placement of point symbols in the AR environment in comparison with an analogue map. Red dotted arrows have been used to present the distance from the observed object in metres. The AR system is characterised by extraordinary dynamics of presentation, with an egocentric view that changes together with any movement on the part of the observer. The conveyance of spatial information is handled by signatures, which should be considered as the thematic content, and by the actual camera image - the basic content. Of key importance in the process of using visual variables is making it possible for the user to optically combine two levels of spatial information reception. 

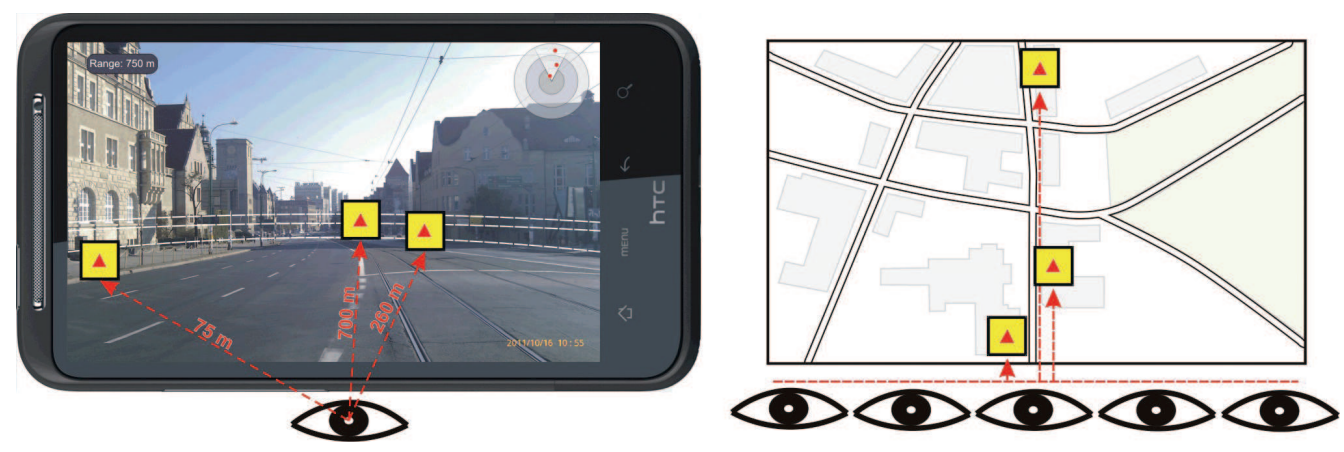

Fig. 4. The difference in dislocation of point symbols In the AR and tourist maps

When referring to AR, Gotlib (2011) mentions the necessity of adapting graphical or textual elements superimposed on top of the real world image, which has an infinite number of forms. This image is characterised, among others, by varying colour, brightness and contrast.

The main features of map applications created in the AR environment include:

- egocentricity - this manifests itself in the utilisation of Location-Based Services and the geovisualisation of objects in a central perspective.

- dynamism of visualisation - this manifests itself in two aspects:

- dynamism of the base, that is the real world image viewed through the lens of the smartphone's camera. The user's movement causes a change as regards the presentation of background content information;

- the dynamism of symbols manifests itself in the possibility of applying animations in addition to the static visual variables; these animations are triggered by specific events or are displayed throughout the period of presentation of the symbol.

The dynamism of visualisation possibilities constitutes a challenge to cartographers. This concerns the design of sets of symbols with the appropriate parameters of graphical variables, which will be adapted both to the presentation of spatial information under varying lighting conditions, and to the method of usage.

\subsection{Degrees of usefulness of static visual variables in AR systems}

The appropriately selected parameters of visual variables constitute a key element of the process of cartographic message. In the process of cartographic design, the issue of selecting visual variables - the objective of which is to present specific qualitative and quantitative information - is of the utmost importance. First and foremost, the appropriate selection impacts the ease of use of the map application, i.e. the speed with which semantic features of objects are localised and properly read on the smartphone screen. Bertin mentions four characteristics (Fig. 5) of visual variables: 


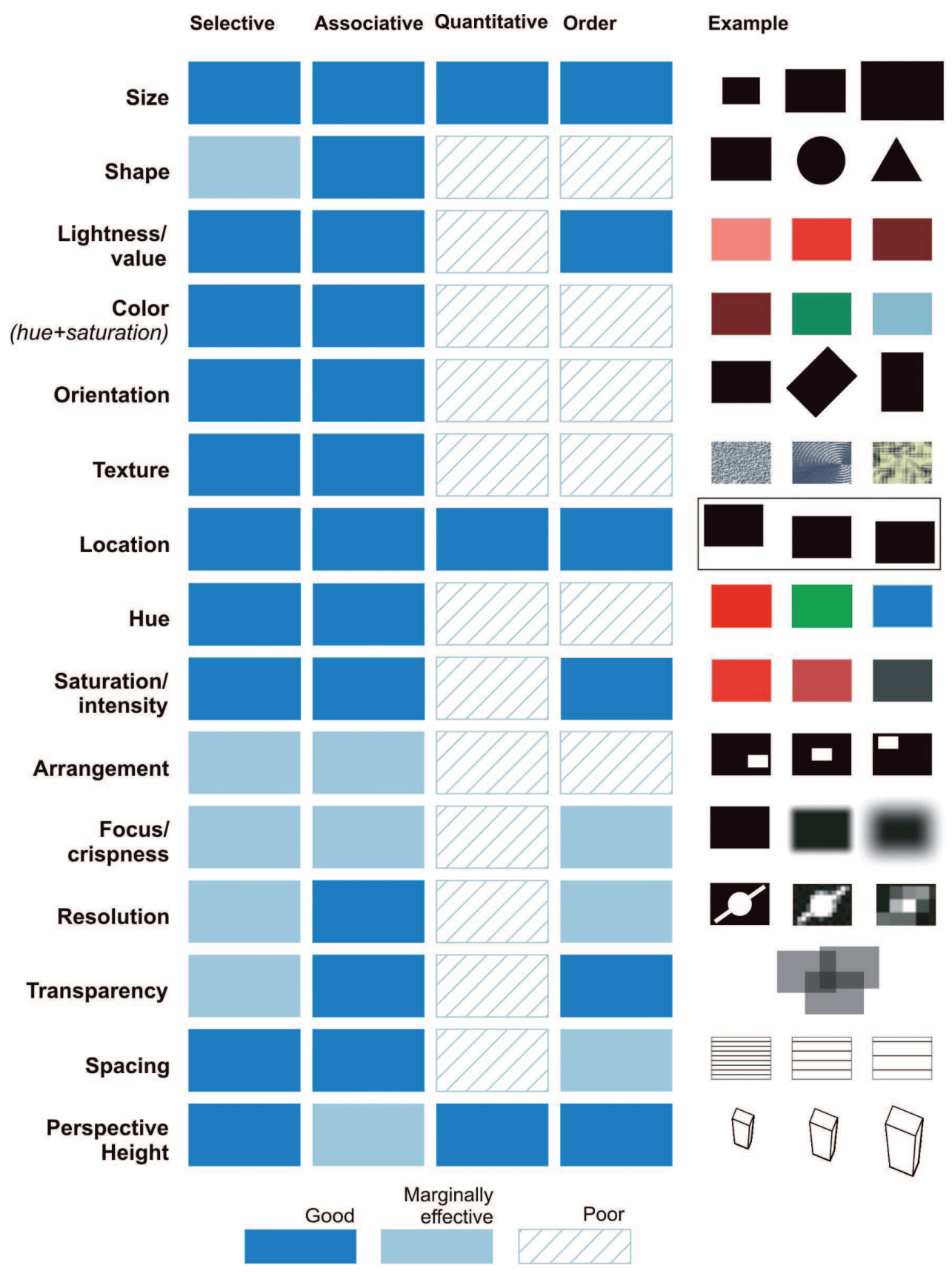

Fig. 5. Characteristics of visual variables to be implemented in AR systems 
selective, associative, quantitative and order. These make it possible to classify visual variables in terms of their usefulness or uselessness when presenting specific semantic features (Carpendale, 2003).

According to Carpendale (2003), these characteristics may be described as follows:

- Selective - a visual variable is said to be selective if a mark changed in this variable alone makes it easier to select that changed symbol from all the other symbols (later called visual isolation by MacEachren (1995)).

- Associative - a visual variable is said to be associative if marks that are like in other ways can be grouped according to a change in this visual variable. This means that several symbols can be grouped together across changes in other visual variables (later called visual levels by MacEachren (1995)).

- Quantitative - a visual variable is said to be quantitative if the relationship between two symbols differing in this visual variable can be seen as numerical. For instance one line can be seen as being two times as long as another line.

- Order - a visual variable is said to be ordered if changes in this visual variable support ordered perception. That is a change in an order visual variable will automatically be read as either more or less.

In Figure 5 we have presented the degree of usefulness of individual characteristics of fifteen static visual variables. Summary was created based on a query of literature and theoretical considerations of the author. A good level of selectivity is typical of the following: size, lightness/value, color, orientation, texture, location, hue, saturation/intensity, transparency, spacing, perspective height. Using the above-mentioned variables, it is possible to isolate an exemplary symbol from amongst a group of symbols. As regards associativity, the following variables are recommended: size, shape, lightness/value, color, orientation, texture, location, hue, saturation/intensity, resolution, spacing and transparency. Using the aforementioned variables, one may isolate a few objects as a group with common features. The research of literature suggests that only three visual variables (location, size and perspective height) of the listed fifteen variables can represent quantitative characteristics of a given object. The following are the best variables for presenting order: size, lightness/value, location, saturation/intensity, perspective height and transparency.

During the process of elaborating a correct cartographic message for the smartphone in the AR system, one should take into consideration, among others, the degree of usefulness of a given variable with reference to appropriate features. Figure 6 contains two proposals for the visualisation of the distance between the observer and the observed objects by means of an identical shape and colour hue, yet a variable size, and transparency.

On existing classic maps, the visual variable size presents the quantitative diversity between objects. It indicates the magnitude of a given phenomenon - the greater a phenomenon/object, the greater the symbol. In the visualisation used in AR systems, the magnitude of a symbol shows the change in the distance between the object in question and the observer. The closer the object is to the observer, the larger the signature. In the author's opinion, the application of the size variable allows a better reflection of 

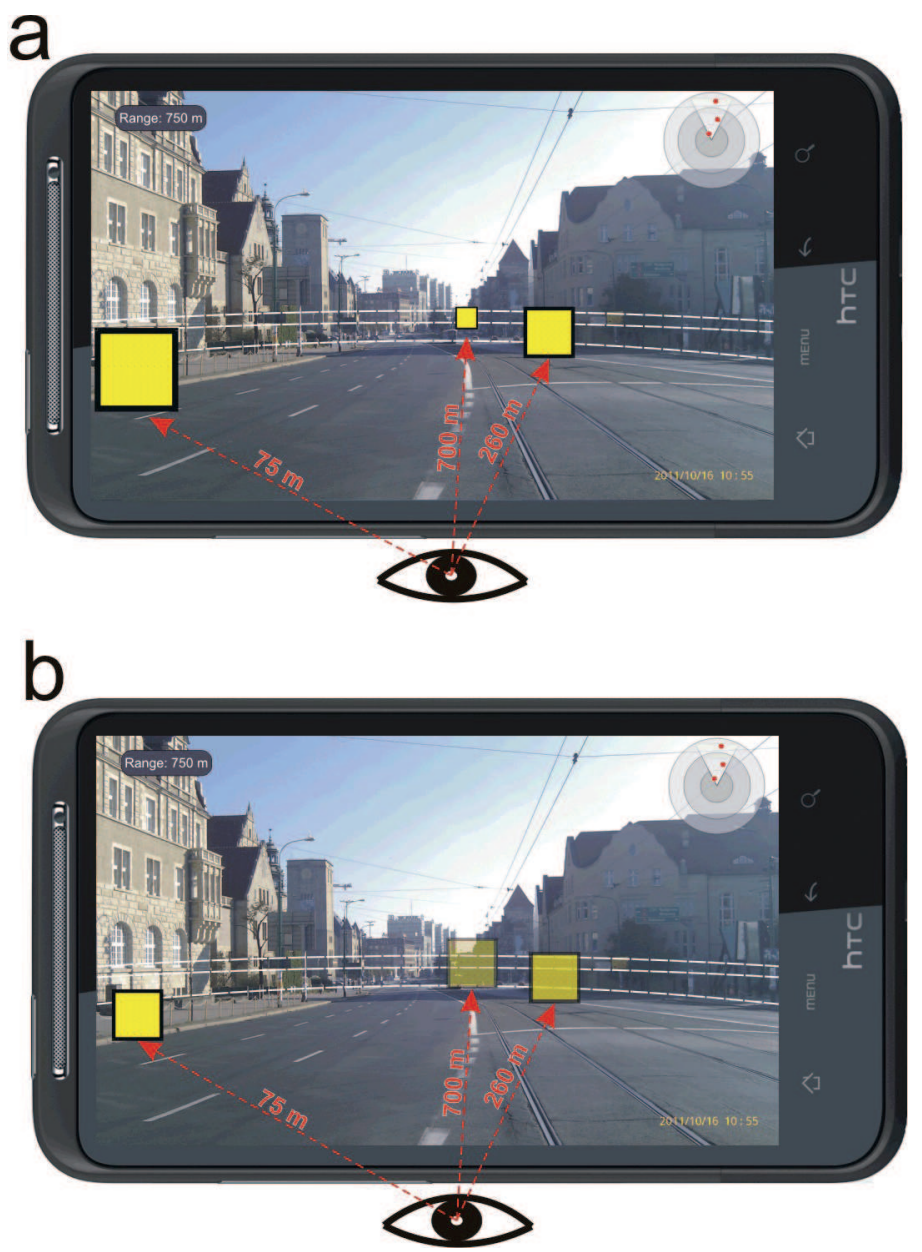

Fig. 6. The use of visual variables: a) size, b) transparency

the observer-observed object relation than that of the transparency variable. Signatures with considerable transparency that are far away from the observer have insufficient visual contrast with the camera image and become illegible.

\section{Summary}

In the present deliberations, we have presented the development of the scientific theory of static visual variables described over the years using a breakdown. An attempt was made to provide an overview of static visual variables. The author has presented the basic components of smartphone-type devices supporting AR implementation, which impact the possibility of adapting visual variables to being viewed by the user from a central perspective. An analysis was performed of visual variables on the basis of 
the following characteristics: selective, associative, quantitative and order. Methods of visualising the distance to point objects in the AR system, between the user of the map application and the observed object, were proposed as a new approach.

A discussion concerning static visual variables and their impact on the process of cartographic message points to the necessity of analysing dynamic visual and sonic variables. Furthermore, the present article constitutes a point of departure for empirical research, which will help find an answer to the question as to which ranges of values of individual variable parameters are most suitable for usage in the AR system for smartphones in the process of designing cartographic symbols.

\section{Acknowledgments}

I would like to thank to my $\mathrm{PhD}$ advisor, Professor Beata Medynska-Gulij for her valuable feedback on all things related to cartographic design methods.

\section{References}

Azuma, R.T. (1997). A Survey of Augmented Reality. Teleoperators and Virtual Environments, 6, 355-385. Berfield, W. Et Caudell, T. (2001). Basic Concepts in Wearable Computers and Augmented Reality, In Fundamentals of Wearable Computers and Augmented Reality. (Eds.), Barfield W., Caudell T., (3-26), Lawrence Erlbaum, Mahwah, N.J.

Bertin, J. (1967/83). Semiology of Graphics: Diagrams, Networks, Maps. Wisconsin: Uniwersity of Wisconsin Press. (first published in French in 1967 translated by William J. Berg in 1983).

Butchart, B. (2011), Architectural Styles for Augmented Reality in Smartphones. In Third International AR Standards Meeting, 15-16 June 2011 (pp. 1-7). Taichung, Taiwan: Open Geospatial Consortium.

Carpendale, M.S.T. (2003). Considering visial variables as a basis for information visualization. Calgary, Canada: University of Calgary.

Danado, J. Dias, E. Romao, T. Correi, N. Trabuco, A. Santos, C. Serpa, J. Costa, M. Et Camaro, A. (2005). Mobile Environmental Visualization. The Cartographic Journal 42(1), 61-68.

Dent, B.D. Torguson, J. Et Holder, T.W. (2009). Cartography: Thematic Map Design (6th ed.). New York: McGraw-Hill Higher Education.

Gotlib, D. (2011). Methods of cartographic presentation for mobile navigation and location based systems. (In Polish). Warszawa: Oficyna Wydawnicza Politechniki Warszawskiej.

Höllerer, T.H. Et Feiner, S.K. (2004). Mobile Augmented Reality. In Telegeoinformatics: Location-Based Computing and Services. Karimi H. Et Hammad A. (eds.), Tylor \& Francis Books Ltd.

Kraak, M.J. Et Ormeling, F. (2003). Cartography: Visualization of Geospatial Data (2nd ed.). New York: Prentice Hall.

Krygier, J.B. Et Wood, D. (2005). Making Maps: A Visual Guide to Map Design for GIS. New York: Guilford Press.

MacWilliams, A. Reicher, T. Klinker, G. Et Bruegge, B. (2004). Design Patterns for Augmented Reality Systems. In International Workshop exploring the Design and Engineering of Mixed Reality SystemsMIXER, 2004, Funchal, Madeira, CEUR Workshop Proceedings.

MacEachren A.M., (1995): How Maps Work: Representation, Visualization and Design. New York: Guilford Press.

Medyńska-Gulij, B. (2008). Point Symbols: Investigating Principles and Originality in Cartographic Design. The Cartographic Journal, 45 (1), 62-67.

Medyńska-Gulij, B. (2011). Cartography and geovisualization. (In Polish) Warszawa: Państwowe Wydawnictwo Naukowe. 
Meng, L. (2005). Egocentric design of map-based mobile services. The Cartographic Journal, 42(1), 5-13. Morrison, J.L. (1974). A theoretical framework for cartographic generalization with the emphasis on the process of symbolization. International Yearbook of Cartography, 14, 115-127.

Schmalstieg, D. Et Reitmayr, G. (2006). Augmented Reality as a Medium for Cartography, In: Cartwright W., Peterson M.P. Et Georg G. Multimedia Cartography (2nd ed.), (pp. 267-282). Springer Verlag Berlin and Heidelberg GmbH \& Co. K.

Slocum, T.A. McMaster, R.B. Kessler, F.C. Et Howard, H.H. (2010). Thematic Cartography and Geovisualization (3rd ed.). London: Pearson Education LTD.

Špatenková, O. Demšar, U. Et Krisp, J. (2007). Self-Organising Maps for exploration of spatio-temporal emergency response data. 9 th International Conference on Geocomputation 3-5 September 2007.

Tyner, J.A. (2010). Principles of Map Design. New York: The Guilford Press.

\title{
Analiza zmiennych wizualnych pod kątem wykorzystania w projektowaniu znaków punktowych dla mobilnych aplikacji tworzonych w technologii Rzeczywistości Rozszerzonej
}

\section{Lukasz Halik}

\author{
Zakład Kartografii I Geomatyki, Uniwersytet im. Adama Mickiewicza w Poznaniu, \\ Collegium Geographicum, ul. Dziegielowa 27, 61-680 Poznań \\ e-mail: 1halik@amu.edu.p
}

\section{Streszczenie}

Celem artykułu było usystematyzowanie wiedzy na temat statycznych zmiennych wizualnych, które są kluczowymi składnikami budującymi sygnatury kartograficzne. Podjęto próbę zestawienia zmiennych wizualnych wyodrębnionych przez kartografów na przestrzeni ostatnich pięćdziesięciu lat, zaczynając od klasyfikacji przedstawionej przez J. Bertin'a. Dokonano analizy stopnia użyteczności poszczególnych zmiennych graficznych w aspekcie ich wykorzystania w projektowaniu znaków punktowych dla mobilnych aplikacji tworzonych w technologii Rzeczywistości Rozszerzonej (Augmented Reality). Zmienne poddano analizie pod względem czterech charakterystyk: selektywności, skojarzeniowości, odzwierciedlenia ilości oraz porządku.

W artykule zwrócono uwagę na odmienne zastosowanie perspektywy pomiędzy tradycyjnymi analogowymi mapami (geocentryczność) a aplikacjami tworzonymi w technologii Rozszerzonej Rzeczywistości (egocentryczność). Treści prezentowane w pracy dotyczą szybko rozwijającej się gałęzi kartografii - kartografii mobilnej. Dodatkowy nacisk położony został na próbę implementacji założeń projektowania punktowych znaków kartograficznych na urządzenia mobilne typu smartphone. 